\title{
The Effect of Captopril on Brain Apoptosis After Burn Injury in Rats
}

\author{
Yanık Sonrası Rat Beyninde Meydana Gelen Apoptozis Üzerine \\ Kaptoprilin Etkisi
}

\author{
Ibrahim Yaman SAGLAM ${ }^{1}$, Emine Nur OZDAMAR ${ }^{2}$, Ebru DEMIRALAY ${ }^{3}$, Ahmet Ozer SEHIRLI ${ }^{4}$, \\ Goksel SENER ${ }^{4}$, Esra SAGLAM ${ }^{5}$ \\ ${ }^{1}$ Goztepe Park Medical Hospital, Medical Genetics Laboratory, Istanbul, Turkey \\ ${ }^{2}$ Maltepe University, Faculty of Medicine, Department of Medical Pharmacology, Istanbul, Turkey \\ ${ }^{3}$ Baskent University, Faculty of Medicine, Department of Pathology, Istanbul, Turkey \\ ${ }_{4}^{4}$ Marmara University, Faculty of Pharmacy, Department of Pharmacology, Istanbul, Turkey \\ ${ }_{5}$ Uskudar University, Istanbul Neuropsychiatry Hospital, Laboratory of Clinical Pharmacogenetics, Istanbul, Turkey
}

Corresponding Author: Esra SAGLAM / E-mail: esra.k.saglam@gmail.com

\begin{abstract}
AIM: The purpose of this study was to determine the possible protective effects of captopril treatment against apoptosis in the brain induced by burn injury.

MATERIAL and METHODS: Under ether anaesthesia, Wistar albino rats (200-250 g) were exposed to a 900C (burn) or 250C (sham) water bath for $10 \mathrm{~s}$. The ACE group was treated with i.p. $10 \mathrm{mg} / \mathrm{kg}$ captopril immediately after burn injury and this treatment was repeated twice daily. At the end of the 24 hours, brain samples were taken. Apoptotic brain cells marked by terminal deoxynucleotidyl transferase-mediated d-UTPnick end labeling (TUNEL) were evaluated in the cerebellum and midbrain of rats.

RESULTS: Apoptotic cells in the cerebellum were significantly decreased after captopril treatment and found to be lower when compared to the burn group $(p<0.001)$. In the midbrain of rats, the numbers of TUNEL-positive cells and apoptotic bodies were significantly increased in the burn group when compared to the control group $(p<0.001)$. The burn-induced changes were reduced in the captopril-treated burn group $(\mathrm{p}<0.01)$.
\end{abstract}

CONCLUSION: Captopril has beneficial effects in burn injury and should be assessed as a therapeutic agent in the management of this condition.

KEYWORDS: Captopril, Apoptosis, Burn injury, TUNEL

ÖZ

AMAÇ: Yanığın indüklediği, beyinde meydana gelen apoptozise karşı kaptoprilin koruyucu etkisini araştırmak amaçlanmıştır.

YÖNTEM ve GEREÇLER: Anestezi altındaki Wistar albino sıçanlar (200-250 g) 900C (yanık) ya da 250C (sham-kontrol) su buharına 10 dakika süresince tutuldu. Sıçanlar, yanık oluşumunu takiben i.p. $10 \mathrm{mg} / \mathrm{kg}$ kaptopril ile günde iki kez olmak üzere tedavi edildi. Serebellum ve orta beyinden çıkarılan hücrelerde apoptozun saptanmasında terminal deoxynucleotidyl transferase- mediated d-UTP- (TUNEL) yöntemi kullanıldı.

BULGULAR: Yanık grubu ve sham-kontrol grubu serebellum bölgesinde oluşmuş olan apoptotik hücre sayısı açısından karşılaştırıldığında, TUNEL-positif apoptotik hücre sayısı yanık grubunda anlamlı olarak artmış bulundu $(p<0.001)$. Serebellumdaki apoptotik hücre sayısının, kaptopril tedavisinden sonra, yanık grubu ile karşılaştırıldığında anlamlı olarak azaldığı görüldü $(p<0.001)$. Ortabeyinde ise, apoptotik TUNELpositif hücre sayısı yanık ve kontrol grubu karşılaştıııldığında, yanık grubunda anlamlı olarak arttığı gözlendi $(p<0.001)$, yanığın indüklediği apoptotik değişiklikler ise kaptopril tedavisi ile anlamlı olarak azaldı $(\mathrm{p}<0.01)$.

SONUÇ: Kaptopril yanık hasarı ile beyinde meydana gelen apoptotik değişiklikleri geri döndürmüştür. Yanık hasarının tedavisinde faydalı bir ilaç olabilir.

ANAHTAR SÖZCÜKLER: Kaptopril, Apoptosis, Yanık hasarı, TUNEL

\section{INTRODUCTION}

Apoptosis, or programmed cell death, is an important genecontrolled cell condition. It is a distinct type of cell death characterised by a series of typical morphological events, such as shrinkage of the cell, fragmentation into membrane-bound apoptotic bodies and rapid phagocytosis into neighbouring cells without induction of an inflammatory response (20). The biochemical hallmark of apoptosis is internucleosomal DNA fragmentation (46).

Angiotensin-converting enzyme (ACE) inhibitors have been routinely used to treat heart failure and hypertension. Traditionally, ACE inhibitors block the conversion of 
angiotensin I to angiotensin II. Angiotensin II is a potent vasoconstrictor hormone;in addition to its known vital role in both cardiovascular and fluid homeostasis, several lines of evidence implicate angiotensin II in ischemic neuronal injury via the angiotensin II receptor subtype AT1 (AT1R) (42). Stimulation by angiotensin II of the AT2 receptors with activation of pathophysiologic pathways apoptosis (47). It is known that apoptosis plays an important role in tissue remodelling in pathological conditions. Captopril has recently been found to inhibit Fas-induced apoptosis in human activated T cells (7) and lung epithelial cells (41). Moreover, the neuroprotective effects of ACE inhibitors have been verified in histological studies (45).

Burn injuries are a significant cause of death and disability around the world (11). A significant incidence of multiple organ (liver, thymus, spleen, skeletal muscle, lung, heart and brain) dysfunction and failure has been noted in both animals and humans surviving the initial insult of severe burn injury. This failure of different organ systems is thought to be, at least in part, due to increased apoptotic cell death (21). Following severe burn injury, there is also an increase in signalling pathways such as the p38 and Jnk MAPKs (mitogen-activated protein kinases), leading to an amplification of cytokine production and the initiation of apoptosis $(8,10,49,50)$. With respect to the brain, previous studies have demonstrated that the brain is one of the remote organs subject to injurious effects following severe burn injury $(4,12,24,31,33,50)$. In animal studies of burn injury, magnetic resonance imaging has identified marked changes in the brain up to three days post-burn injury, most notably brain swelling and lesions (24). Over the initial 24 hour post-burn period, rats were found to display decreased glucose utilisation in the brain; however, by week three, the glucose utilisation returned to baseline, indicating an acute dysregulation of glucose metabolism in the brain (2). In behavioural studies, such animals appear to have long-term cognitive deficits associated with a disruption in the blood-brain barrier $(27,39,40)$, increased inflammation (31) and/or altered metabolism in the brain $(2,50)$.

In the light of these findings, we aimed to investigate whether and to what extent captopril would provide protection against burn-induced apoptosis. This study was designed to determine the possible protective effect of captopril treatment against apoptosis in the brain induced by burn injury.

\section{MATERIAL and METHODS}

\section{Animals and Laboratory}

All experimental protocols were approved by the Marmara University Animal Care and Use Committee. Wistar albino rats of both sexes, weighing 200 to $250 \mathrm{~g}$, were obtained from Marmara University School of Medicine Animal House. Rats were kept in a temperature-controlled room $\left(22 \pm 1^{\circ} \mathrm{C}\right)$ with 12-h: 12-h light and dark cycles; they were fed with standard rat chow and fasted for $12 \mathrm{~h}$ before the experiments.

\section{Thermal Injury}

Under brief ether anaesthesia, the dorsum of each rat was shaved and exposed to a $90^{\circ} \mathrm{C}$ water bath for $10 \mathrm{~s}$. This procedure has been shown to result in a second-degree skin burn involving $30 \%$ of the total body surface area (36). To rule out the effects of anaesthesia, the same protocol was applied in the sham group, except that the dorsums were dipped in a $25^{\circ} \mathrm{C}$ water bath for $10 \mathrm{~s}$. After sham or burn injury, rats were resuscitated with physiological saline solution ( $10 \mathrm{ml} / \mathrm{kg} \mathrm{s.c)}$. Each group consisted of eight rats. ACE inhibitor captopril (10 $\mathrm{mg} / \mathrm{kg}$, i.p.; Sigma-Aldrich, St Louis, MO, USA) or saline was given intraperitoneally to rats immediately after the burn injury, and the injections were repeated twice a day. Control group rats did not receive captopril and eight rats in the burn group received captopril.

Rats were decapitated and brain samples were collected at 24 $\mathrm{h}$ after burn injury. The brain samples were sent to Baskent University Istanbul Hospital Pathology Laboratory in 10\% formaldehyde tamponade solution. Samples from tissues of the cerebellum and midbrain were taken for routine tissue processing and paraffin blocks were prepared. Two micrometre-thick sections were affixed to slides.

\section{TUNEL Staining}

The level of DNA fragmentation was detected by in situ terminal deoxynucleotidyl transferase-mediated dUTP nickendlabelling (TUNEL) using an ApopTag in situ apoptosis detection kit (Millipore, USA\& Canada) according to the manufacturer's instructions. Briefly, deparaffinised and rehydrated sections were pretreated with $20 \mu \mathrm{g} / \mathrm{mL}$ proteinase $\mathrm{K}$ for $15 \mathrm{~min}$ at room temperature. After the slides were washed twice with PBS, the sections were incubated in equilibration buffer for $30 \mathrm{~min}$. The sections were then incubated with the labelling solution containing terminal deoxynucleotidyl transferase in a humidified chamber for $1 \mathrm{~h}$ at $37^{\circ} \mathrm{C}$. The reactions were terminated by rinsing the sections in a stop/wash buffer. The sections were incubated with antidigoxigenin conjugate for $30 \mathrm{~min}$ at room temperature and then rinsed four times in PBS. The TUNEL-labelled slides were photographed using a fluorescence microscope.

\section{Statistical Analysis}

Statistical analysis of data was performed by one-way analysis of variance (ANOVA) with Tukey's test using a statistical software package (GraphPad Prism 3.0, San Diego,CA,USA). Values of $p<0.01$ were regarded as significant.

\section{RESULTS}

Two brain areas were examined, the cerebellum and the midbrain, where TUNEL-positive cells indicating apoptosis were shown to increase at $24 \mathrm{~h}$ after a systemic inflammation model (35). A marked increase in the number of apoptotic cells was seen in the cerebellum and midbrain of burned rats $24 \mathrm{~h}$ after burn injury by in situ TUNEL staining. The apoptotic cells showed characteristic shrinking, chromatin clumping and nuclear fragmentation. Captopril treatment reduced the 
numbers of apoptotic cells in both brain areas (Figure 1A-C, $2 A-C)$.

In the cerebellum, the number of TUNEL-positive cells and apoptotic bodies in the burn group was found to be significantly higher than in the sham control group $(p<0.001)$. Apoptotic cells in the cerebellum were significantly decreased after captopril treatment and found to be lower when compared to the burn group $(p<0.001)$. However, in the captopril-treated burned rats, the number of TUNEL-positive cells was not significantly different from that in the control rats (Figure 3).

In the midbrain of rats, the numbers of TUNEL-positive cells and apoptotic bodies were significantly increased in the burn group when compared to the control group $(p<0.001)$. The burn-induced changes were reduced in the captopril-treated burn group $(p<0.01)$ (Figure 4$)$.

\section{DISCUSSION}

Apoptosis is an orchestrated form of cell 'death by suicide'. It is essential in both the development and normal maintenance of tissue function. Apoptotic nerve cell death is implicated in the pathogenesis of several devastating neurodegenerative conditions. Neuronal apoptosis occurs in several brain diseases, including Parkinson's disease (22), ischemia-reperfusion injury (48), encephalopathy and sepsis (19). Systemic inflammation induces apoptosis with variable vulnerability of different brain regions (35). Neuronal apoptosis has a potentially important role in burn injury.

The ACE inhibitor captopril blocks the conversion of angiotensin I to the potent vasoconstrictor angiotensin II and simultaneously inactivates the vasodilator peptide bradykinin. Besides its blood pressure-lowering properties, captopril has various immunomodulatory functions. The drug exhibits beneficial effects on rheumatoid arthritis $(14,26)$ and prevents complications in insulin-dependent diabetes mellitus (23). Additionally, captopril successfully inhibits inflammation in schistosomiasis (44), experimental lupus diseases (13) and experimental autoimmune encephalomyelitis (EAE) (6). Some ACE inhibitors-including captopril-are capable of suppressing the production of monocytes/macrophagederived proinflammatory cytokines such as tumour necrosis factor (TNF), interleukin (IL)-1, IL-6 and IL-12 (5,9,34). These immunomodulatory actions of captopril have been explained by several mechanisms, including anti-proliferation $(1,3,29,37)$, anti-oxidant activity $(15,16,32)$, inhibition of metalloproteases $(28,38)$ and elevation of prostaglandin
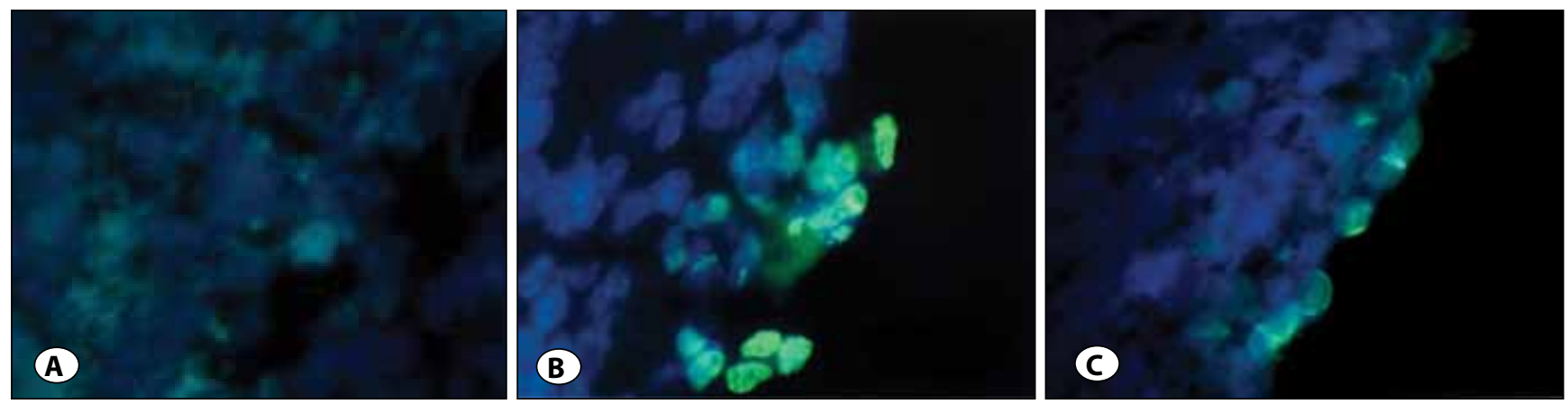

Figure 1: Detection of DNA fragmentation in the cerebellum was performed using the in situ terminal deoxynucleotidyl transferase dUTP nick-end labelling (TUNEL) method, as described in MATERIALS AND METHODS. TUNEL staining revealed increased numbers of fluorescent-stained nuclei consistent with apoptosis in the cerebellum of burned rats compared with sham control rats. Captopril treatment reduced the numbers of apoptotic cells. A) Control group, B) Burn group, C) Burn and captopril group.
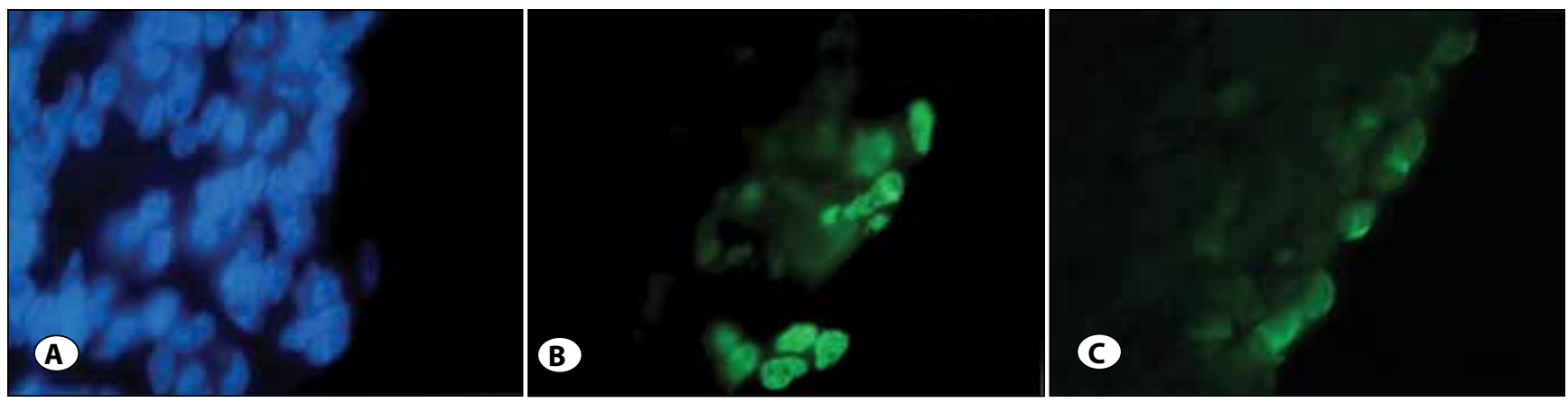

Figure 2: Detection of DNA fragmentation in the midbrain was performed using the in situ terminal deoxynucleotidyl transferase dUTP nick-end labelling (TUNEL) method, as described in MATERIALS AND METHODS. TUNEL staining revealed increased numbers of fluorescent-stained nuclei consistent with apoptosis in the midbrain of burned rats compared with sham control rats. Captopril treatment reduced the numbers of apoptotic cells. A) Control group, B) Burn group, C) Burn and captopril group. 


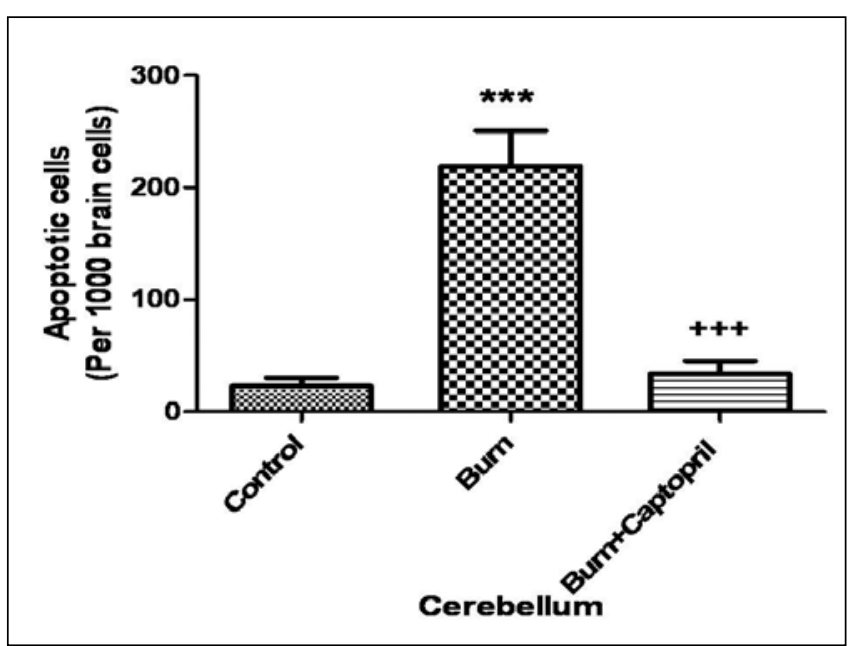

Figure 3: Apoptotic cell number as terminal deoxyuridine nickend labelling (TUNEL)-positive cells or apoptotic bodies per 1,000 brain cells. The figure shows the number of TUNEL positive cells in the cerebellum of the burn, control and captopril-treated burn groups. Each group consists of four animals. ${ }^{* *} p<0.001$; compared to control group. ${ }^{++} p<0.001$; compared to burn group.

$(17,18,25)$. Some of these properties may be related to the presence of thiol groups in its structure and are independent of its effect on the renin angiotensin system $(30,43)$. As captopril has recently been found to inhibit Fas-induced apoptosis in human activated T cells (7) and lung epithelial cells (41), we hypothesise that prevention of apoptosis could be one of the mechanisms bringing about the efficacy of ACE inhibitors. Captopril has a long-acting effect, can be used once daily and is welcomed by clinicians and patients.

In conclusion, in this study, we showed that captopril inhibited two examined brain areas, the cerebellum and the midbrain, where TUNEL-positive cells indicating apoptosis were shown to increase at $24 \mathrm{~h}$ after a systemic inflammation model (35). Captopril may interfere with to provide protection from apoptotic cell death resulting from burn injuries. Our data indicate that captopril has beneficial effects in burn injury and should be assessed as a therapeutic agent in the management of this condition.

\section{REFERENCES}

1. Bauer $\mathrm{H}$, Lametschwandtner A, Steiner M, Bauer HC: Influence of angiotensin converting enzyme inhibitor (captopril) on kidney epithelial cells in vitro: Studies on potassium (86Rb) influx and cellular proliferation. Clin Chim Acta 187:47-53, 1990

2. Carter EA, Tompkins RG, Babich JW, Correia JA, Fischman AJ: Decreased cerebral glucose utilization in rats during the ebb phase of thermal injury. J Trauma-Injury Infection \& Critical Care 40(6):930-935, 1996

3. Chen L, Re RN, Prakash O, Mondal D: Angiotensin-converting enzyme inhibition reduces neuroblastoma cell growth rate. Proc Soc Exp Biol Med 196:280-283, 1991

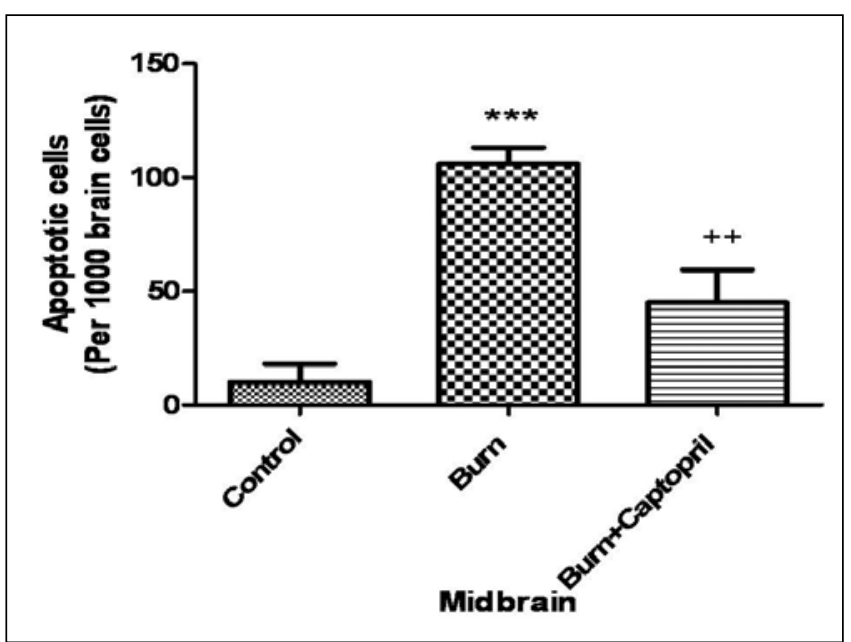

Figure 4: Apoptotic cell number as terminal deoxyuridine nickend labelling (TUNEL)-positive cells or apoptotic bodies per 1,000 brain cells. The figure shows the number of TUNEL positive cells in the midbrain of the burn, control and captopril-treated burn groups. Each group consists of four animals. ${ }^{* * *} p<0.001$; compared to control group. ${ }^{++} \mathrm{p}<0.01$; compared to burn group.

4. Cho SJ, Minn YK, Kwon KH: Stroke after burn. Cerebrovasc Dis 24(2-3):261-263, 2007

5. Constantinescu CS, Goodman DB, Ventura ES: Captopril and lisinopril suppress production of interleukin-12 by human peripheral blood mononuclear cells. Immunol Letters 62: 25-31, 1998

6. Constantinescu CS, Ventura E, Hilliard B, Rostami A: Effects of the angiotensin converting enzyme inhibitor captopril on experimental autoimmune encephalomyelitis. Immunopharmacol Immunotoxicol 17:471-491, 1995

7. Deas O, Dumont C, Mollereau B, Metivier D, Pasquier C, Bernard-Pomier G, Hirch F, Charpentier B, Senik A: Thiolmediated inhibition of FAS and CD2 apoptotic signaling in activated human peripheral T cells. Int Immunol 9(1): 117-125, 1997

8. Duan H, Chai J, Sheng Z, Yao Y, Yin H, Liang L, Shen C, Lin $\mathrm{J}$ : Effect of burn injury on apoptosis and expression of apoptosis-related genes/proteins in skeletal muscles of rats. Apoptosis 14(1):52-65, 2009

9. Fukuzawa M, Satoh J, Sagara M, Muto G, Muto $Y$, Nishimura S, Miyaguchi S, Qiang XL, Sakata Y, Nakazawa T, Ikehata F, Ohta S, Toyota T: Angiotensin converting enzyme inhibitors suppress production of tumor necrosis factor-alpha in vitro and in vivo. Immunopharmacology 36:49-55, 1997

10. Fukuzuka K, Rosenberg JJ, Gaines GC, Edwards CK 3rd, Clare-Salzler M, MacKay SL, Moldawer LL, Copeland EM 3rd, Mozingo DW: Caspase-3-dependent organ apoptosis early after burn injury. Ann Surg 229(6):851-859, 1999

11. Grunwald TB, Garner WL: Acute burns. Plast Reconstr Surg 121(5): 311e-319e, 2008

12. Halm MP, Poquin D, Lestaevel $P$, Chancerelle $Y$, Graff $C$ : Brain and cognitive impairments from burn injury in rats. Burns 32(5):570-576, 2006 
13. Herlitz H, Tarkowski A, Svalander C, Volkmann R, Westberg G: Beneficial effect of captopril on systemic lupus erythematosus-like disease in MRL Ipr/lpr mice. Int Arch Allergy Appl Immunol 85:272-277, 1988

14. Jaffe I: Angiotensin converting inhibitors in rheumatoid arthritis. Arthritis Rheum 27(7):840, 1984

15. Jay D: Captopril and glutathione inhibit the superoxide dismutase activity of $\mathrm{Hg}$ (II) Arch Inst Cardiol Mex 68:457-461, 1998

16. Jay $D$, Cuella $A$, Jay E: Superoxide dismutase activity of the captopril-iron complex. Mol Cell Biochem 146:45-47, 1995

17. Johnsen SA, Aurell M: Immunosuppressive action of captopril blocked by prostaglandin synthetase inhibitor. Lancet 1:1005, 1981

18. Johnsen SA, Persson IB, Aurell M: PGE2 production after angiotensin-converting enzyme inhibition. Scand J Urol Nephrol 31:81-88, 1997

19. Kafa IM, Uysal M, Bakirci S, Ayberk Kurt M: Sepsis induces apoptotic cell death in different regions of the brain in a rat model of sepsis. Acta Neurobiol Exp 70: 246-260, 2010

20. Kerr JFR, Wyllie AH, Currie AR: Apoptosis: a basic biological phenomenon with wide-ranging implications in tissue kinetics. Br J Cancer 26: 239-257, 1972

21. Kowal-Vern A, Walenga JM, Sharp-Pucci M, Hoppensteadt D, Gamelli RL: Postburn edema and related changes in interleukin-2, leukocytes, platelet activation, endothelin-1, and C1 esterase inhibitor. J Burn Care Rehabil 18(2):99-103, 1997

22. Lev N, Melamed E, Offen D: Apoptosis and Parkinson's disease. Prog Neuropsychopharmacol Biol Psychiatry 27(2):245250, 2003

23. Lewis EJ, Hunsicker LG, Bain RP, Rohde RD: The effect of angiotensin-converting-enzyme inhibition on diabetic nephropathy. N Engl J Med. 329(20):1456-1462, 1993

24. Li H, Ying D, Sun J, Zhang Y, He B: Comparative observation with MRI and pathology of brain edema at the early stage of severe burn. Chin J Traumatol 4(4):226-230, 2001

25. Linz W, Wiemer G, Gohlke P, Unger T, Scholkens BA: Contribution of kinins to the cardiovascular actions of angiotensinconverting enzyme inhibitors. Pharmacol Rev 47:25-49, 1995

26. Martin MF, Surrall KE, McKenna F, Dixon JS, Bird HA, Wright V: Captopril: A new treatment for rheumatoid arthritis? Lancet 1(8390):1325-1328, 1984

27. McColl BW, Rothwell NJ, Allan SM: Systemic inflammation alters the kinetics of cerebrovascular tight junction disruption after experimental stroke in mice. J Neurosci 28:9451-9462, 2008

28. Nakagawa T, Kubota T, Kabuto M, Kodera T: Captopril inhibits glioma cell invasion in vitro: Involvement of matrix metalloproteinases. Anticancer Res 15:1985-1989, 1995

29. Nguyen L, Ward WF, Ts'ao CH, Molteni A: Captopril inhibits proliferation of human lung fibroblasts in culture: A potential antifibrotic mechanism. Proc Soc Exp Biol Med 205:80-84, 1994
30. Reddy MK, Baskaran K, Molteni A: Inhibitors of angiotensinconverting enzyme modulate mitosis and gene expression in pancreatic cancer cells. Proc Soc Exp Biol Med 210:221-226, 1995

31. Reyes R Jr, Wu Y, Lai Q, Mrizek M, Berger J, Jimenez DF, Barone $C M$, Ding Y: Early inflammatory response in rat brain after peripheral thermal injury. Neurosci Lett 407(1):11-15, 2006

32. Roberts NA, Robinson PA: Copper chelates of antirheumatic and anti-inflammatory agents: Their superoxide dismutaselike activity and stability. Br J Rheumatol 24:128-136, 1985

33. Rosenberg $M$, Robertson $C$, Murphy KD, Rosenberg L, Mlcak R, Robert RS, Herndon DN, Meyer WJ 3rd: Neuropsychological outcomes of pediatric burn patients who sustained hypoxic episodes. Burns 31(7):883-889, 2005

34. Schindler R, Dinarello CA, Koch KM: Angiotensin-convertingenzyme inhibitors suppress synthesis of tumour necrosis factor and interleukin 1 by human peripheral blood mononuclear cells. Cytokine 7:526-533, 1995

35. Semmler A, Okulla T, Sastre M, Dumitrescu-Ozimek L, Heneka MT: Systemic inflammation induces apoptosis with variable vulnerability of different brain regions. Journal of Chemical Neuroanatomy 30:144-157, 2005

36. Sener G, Sehirli A, Satiroglu H, Keyer-Uysal M, C Yeğen B: Melatonin improves oxidative organ damage in a rat model of thermal injury. Burns 28(5):419-425, 2002

37. Small W, Jr, Molteni A, Kim YT, Taylor JM, Chen Z, Ward WF: Captopril modulates hormone receptor concentration and inhibits proliferation of human mammary ductal carcinoma cells in culture. Breast Cancer Res Treat 44:217-224, 1997

38. Sorbi D, Fadly M, Hicks R, Alexander S, Arbeit L: Captopril inhibits the $72 \mathrm{kDa}$ and $92 \mathrm{kDa}$ matrix metalloproteinases. Kidney Int 44:1266-1272, 1993

39. Swann K, Berger J, Sprague SM, Wu Y, Lai Q, Jimenez DF, Barone CM, Ding Y: Peripheral thermal injury causes bloodbrain barrier dysfunction and matrix metalloproteinase (MMP) expression in rat. Brain Res 1129:26-33, 2007

40. Terao S, Yilmaz G, Stokes KY, Russell J, Ishikawa M, Kawase T, Granger DN: Blood cell-derived RANTES mediates cerebral microvascular dysfunction, inflammation, and tissue injury after focal ischemia-reperfusion. Stroke 39:2560-2570, 2008

41. Uhal BD, Gidea C, Bargout R, Bifero A, Ibarra-Sunga O, Papp M, Flynn K, Filippatos G: Captopril inhibits apoptosis in human lung epithelial cells: A potential antifibrotic mechanism. Am J Physiol 275(5):L1013-1017, 1998

42. Walther T, Olah L, Harms C, Maul B, Bader M, Hörtnagl H, Schultheiss HP, Mies G: Ischemic injury in experimental stroke depends on angiotensin II. FASEB J 16: 169-176, 2002

43. Ward WF, Kim YT, Molteni A, Solliday MH: Radiation-induced pulmonary endothelial dysfunction in rats: Modification by an inhibitor of angiotensin converting enzyme. Int J Radiat Oncol Biol Phys 15:135-140, 1988

44. Weinstock JV, Ehrinpreis MN, Boros DL, Gee JB: Effect of SQ 14225 , an inhibitor of angiotensin I-converting enzyme, on the granulomatous response to Schistosoma mansoni eggs in mice. J Clin Invest 67:931-936, 1981 
45. Werner C, Hoffman WE, Kochs E, Rabito SF, Miletich DJ: Captopril improves neurologic outcome from incomplete cerebral ischemia in rats. Stroke 22(7): 910-914, 1991

46. Wyllie AH: Glucocorticoid-induced thymocyte apoptosis is associated with endogenous endonuclease activation. Nature 284:555-556, 1980

47. Yamada T, Horiuchi M, Dzau VJ: Angiotensin II type 2 receptor mediates programmed cell death. Proc Natl Acad Sci USA 93: 156-160, 1996
48. Yuan $Y$, Guo Q, Ye Z, Pingping X, Wang N, Song Z: Ischemic postconditioning protects brain from ischemia/reperfusion injury by attenuating endoplasmic reticulum stress-induced apoptosis through PI3K-Akt pathway. Brain Res 1367: 85-93, 2011

49. Zhang JP, Ying X, Liang WY, Luo ZH, Yang ZC, Huang YS, Wang WC: Apoptosis in cardiac myocytes during the early stage after severe burn. J Trauma 65(2):401-408, 2008

50. Zhang Q, Carter EA, Ma B, Fischman AJ, Tompkins RG: Burnrelated metabolic and signaling changes in rat brain. J Burn Care Res 29(2):346-352, 2008 